\title{
Definition of Success According to Women Entrepreneur in Malang, Indonesia*
}

\author{
Maretha Ika PRAJAWATI ${ }^{1}$, Wahjoedi WAHJOEDI ${ }^{2}$, Hari WAHYONO ${ }^{3}$, Sunaryanto SUNARYANTO ${ }^{4}$
}

Received: July 03, 2020 Revised: July 19, 2020 Accepted: August 10, 2020

\begin{abstract}
This study aims to interpret the meaning of a successful entrepreneur from the perspective of women entrepreneurs in Malang, Indonesia. This research offers a phenomenological approach using purposive sampling. Data was collected by in-depth interviews using structured questionnaire with registered women entrepreneurs in Malang obtained from MSMEs (micro small and medium-sized enterprises) entrepreneurs. The 'continually developing' is one of the meanings of a successful entrepreneur. This study also found that success is when what women do can be useful to others. Besides, the meaning of success has two criteria, i.e., when they can meet their needs (individual satisfaction) and social performance as a goal to be achieved by entrepreneurs. The motivation of women entrepreneurs to establish their venture was not only financial returns, but also personal satisfaction, which was also the indicator of entrepreneurial success for women. This study has several limitations. First, our sample size is too small and consists of entrepreneurs that have an average age above 40 years. Hopefully, further research will be able to generalize our findings to a broader sample in various industries outside the city of Malang. As our research shows, the criteria and meaning of success may be different for a larger sample of entrepreneurs.
\end{abstract}

Keywords: Woman Entrepreneur, Motivation, Financial Economic, Business Sustainability, Entrepreneurial Satisfaction

JEL Classification Code: L26, L31, L32, J16

\section{Introduction}

Many developed countries recognize that small- and medium-sized enterprises (SMEs) play a key role in economic

\footnotetext{
*Acknowledgments:

We would like to thank the member of lecturers in Faculty of Economic UIN Maulana Malik Ibrahim Malang, Indonesia for their support and help.

${ }^{1}$ First Author and Corresponding Author. [1] Doctoral Program, Faculty of Economic, Universitas Negeri Malang, Indonesia. [2] Lecturer, Department of Management, Faculty of Economic, State Islamic University of Maulana Malik Ibrahim Malang, Indonesia [Postal Address: Gajayana Street, Lowokwaru, Malang, East Java, 65144, Indonesia] Email: maretha@uin-malang.ac.id

${ }^{2}$ Lecturer, Faculty of Economic, Universitas Negeri Malang, Indonesia. Email: wahjoedi.fe@um.ac.id

${ }^{3}$ Lecturer, Faculty of Economic, Universitas Negeri Malang, Indonesia. Email: hari.wahyono.fe@um.ac.id

${ }^{4}$ Lecturer, Faculty of Economic, Universitas Negeri Malang, Indonesia. Email: sunaryanto.fe@um.ac.id

(c) Copyright: The Author(s)

This is an Open Access article distributed under the terms of the Creative Commons Attribution Non-Commercial License (https://creativecommons.org/licenses/by-nc/4.0/) which permits unrestricted non-commercial use, distribution, and reproduction in any medium, provided the original work is properly cited.
}

growth. SMEs are dynamic and innovative businesses, where their small size makes it possible to take decisions quickly (Yi, Han and Cha 2018). In Indonesia, SMEs have a crucial role in terms of the growth of skilled and semi-skilled workers and innovation. SMEs also contribute to $99.99 \%$ of the total business entity, 97\% of new employment opportunities and $56-59 \%$ of GDP (gross domestic product). Furthermore, SMEs have also been proven as the only businesses that was not affected by the global crisis in 2008/2009 (Tambunan, 2018).

The ability of SMEs to survive the crisis impact was caused by high local content in their production. High local content not only avoids deterioration due to rupiah depreciation, which can lead to increased production costs in SME businesses that use imported content, but also provide benefits since SMEs can produce commodities with uniqueness and be highly competitive in the market. This condition was caused by products that will be more competitive when they are the best in their class or be the only ones (unique).

The increasing market globalization, the pace of advanced technologies changes in manufacturing, application of nontariff barriers (NTB) by government, and transportation and 
telecommunications have provided opportunities for SMEs to actively penetrate international markets by collaborating with foreign companies (Freeman, Styles, \& Lawley, 2012; Tambunan, 2018). However, currently, the production of SMEs only relies on the local market and domestic demand; the competitive ability for SME products is still quite small and prevents many SMEs from succeeding in exporting. Therefore, how to increase export activity by SMEs has to be the primary concern by the government of Indonesia (Freeman, Styles, \& Lawle, 2012).

In recent years, the involvement of women as entrepreneurs has gained popularity in the world (Reaves, 2008). The increasing of women entrepreneurs in developing countries leads to the increase of entrepreneurial activity at a country level and has changed the scenario of men as 'breadwinners' and women as 'house makers' (Tambunan, 2018). However, the participation rate of women as entrepreneurs in Indonesia has only reached $0.1 \%$ of the total population. This condition will be a challenge in the future to develop women's entrepreneurs.

In general, women entrepreneurs are known as women who manage a business and as housewives who have the primary obligation to maintain the household. Fisher, Maritz, and Lobo (2014) found that, at present, women's participation in the entrepreneurial sector will be higher as more job opportunities open outside their role as housewives, so women need to manage how their roles as housewives and entrepreneurs. Therefore, women will be faced with various obstacles and limitations on how they organize household and business activities. Women entrepreneurs are different from men in the way of thinking, development of products, services, and organizational forms (Satpayeva, Kireyeva, Kenzhegulova, \& Yermekbayeva, 2020).

Understanding what contributes to the entrepreneurial success of SMEs is crucial (Storey, 2011). However, the term of entrepreneurial success is complex and cannot be interpreted the same way among individuals (Csikszentmihalyi, 2003; Dvir, Sadeh, \& Malach-Pines, 2010). Entrepreneurial success needs to be re-conceptualized because its meaning is more than just a financial term (Gorgievski, Bakker, \& Schaufeli, 2010), and performance measurement are not only subjective (Gorgievski, Bakker, \& Schaufeli, 2010; Hall \& Chandler, 2005). Therefore, the non-financial measurement for describing entrepreneurial success also must to be considered (Al-Tmeemy, AbdulRahman, \& Harun, 2010; Davidsson, Delmar, \& Wiklund, 2007; Gorgievski, Bakker, \& Schaufeli, 2010). Nevertheless, there is a dearth of empirical research to measure nonfinancial performance to describe successful entrepreneurs.

The term of success has become different when the entrepreneurs are women, and how they defined success is exciting to observe (Conner \& Prahalad, 1996; Hitt, Ireland, Camp, \& Sexton, 2001). Basically, the model of entrepreneurial success was assumed by the reality that each of the actions was motivated by individuals' desires to achieve the best result that match their passions, ambitions, and goals. These results will reflect and illustrate the meaning of entrepreneurial success, which includes economic, community, and individual aspects. The phenomenon that women can maintain their survival with hard-working and tenacity has inspired this study.

\section{Literature Review}

\subsection{Women Entrepreneurs}

The role of women as significant players in the world of entrepreneurship is not new, although intensive studies on women's entrepreneurship only began in the late 70s. Research in India (Sorokhaibam \& Laishram, 2011) found that women entrepreneurs are driven by factors where they want to be independent to earn income to improve the quality of life and to get recognition from the community. Some women found that they used their skills to help others through entrepreneurial activities.

Women entrepreneurs can be defined as those who pursue opportunities in management without regard to the resources currently available. However, it seems that women's involvement in entrepreneurship is not as active as they can be because people's knowledge about women entrepreneurs is low compared to men entrepreneurs (Alam, Jani, \& Omar, 2011). Although women face various obstacles and limitations, they are still recognized by society as one of the main contributions to the country's economy.

This research was conducted as an effort to reveal the existence of women entrepreneurs in a comprehensive way. Their presence will be revealed through deep meaning, which is observed from their internal and external conditions in some of their activities, so a more accurate and more indepth description is expected to be obtained. By using a qualitative research approach, this research seeks to uncover the meaning of success for women-owned businesses that play an economic role by working to help their family economy amid the limitations and obstacles they face. The first part of this research is to explain the importance of SMEs in the Indonesian economy. Second, it relates to the main barriers and challenges faced by SMEs, and third, it discusses the meaning of success from women entrepreneurs' point of view.

\subsection{The Meaning of Entrepreneurial Success}

Successful entrepreneurs can create strategic positions by managing their resources to meet the expectations of stakeholders. Masuo, Fong, Yanagida, and Cabal (2001) define success in terms of economic and financial 
measurement that include asset returns, sales, employee profits, and survival rates while non-financial measures include customer satisfaction, personal development, and personal achievement. Similarly, Buttner and Moore (1997) revealed that business success is usually measured from an economic perspective such as sales and employee growth or by increasing profits. Because most research focuses on economic or financial aspects in measuring success, the existence of successful women entrepreneur is barely noticed because of their small size and slower growth (Alam, Jani, \& Omar, 2011).

Simpson, Tuck, and Bellamy (2004) define success in the simplest way, namely, sustainable business operations, while business failure means going out of business. They also revealed that most of the literature mentioned that all entrepreneurs have perceptions about what success means. Many factors can cause the success of entrepreneurs, but their self is the determinants of the success of their business (Alam, Jani, \& Omar, 2011). Alam, Jani, and Omar (2011) identified the success factors of women entrepreneurs in the Southern Region of Malaysia and found that family support, social ties, and internal motivation were significant elements influencing their success. Moreover, in terms of facing challenges, several factors contribute to the success of women entrepreneurs such as a confident personality, willingness to take risks, work experience, and innovative ideas (Lai, Nathan, Tan, \& Chan, 2010). Of course, without profit, a business cannot run for a long time. However, only depend on profit to define the success was not realistic (Cooper \& Artz, 1995).

At the company level, most researchers conceptualize the success as company growth by using criteria such as sales, profit, or employee growth (Baum \& Locke, 2004) while non-financial criteria generally used for describing entrepreneurial success was entrepreneur's satisfaction in their business (Gupta \& Govindarajan, 1984). Some literature on social entrepreneurship has described the success with a combination of financial criteria (profitability) with nonfinancial criteria (social and environmental goals). However, social criteria are subjective and often achieved in a long time, making it challenging to be produced and standardized (Arena, Azzone, \& Bengo, 2015; Lumpkin, Moss, Gras, Kato, \& Amezcua, 2013).

\section{Research Methods and Materials}

This research takes a phenomenological approach. Purposive sampling was used to select the participants. Data collection was carried out by conducting in-depth interviews with five successful women entrepreneurs in the fields of food, fashion, and art. The respondents' data were obtained from the Cooperative and MSMEs Office in Malang. The research data were analyzed by involving core processes, namely, epoche, phenomenological reduction, imaginative variation, and synthesis of meaning and essences. The credibility of the results was evaluated by using member checking (Moustakas, 1994).

\section{Results and Discussion}

The company's business performance is one of the goals of every entrepreneur (Luc, 2020). The performance of a company's business can be interpreted as the level of success in achieving the intended targets or objectives. A measure of a company's business success can be assessed from various aspects, such as financial performance and corporate image. According to Satpayeva, Kireyeva, Kenzhegulova and Yermekbayeva (2020), entrepreneurs who can take superior decisions will be able to improve business performance, such as increasing profits and business growth. Company performance is the output of various factors, which is why this measurement is essential to know the level of adaptability of the business. Business performance needs to be linked to company targets determined by the business owner-manager. Whatever the target, business performance is a benchmark to assess how much the level of achievement of a mark or business goal. However, the interpretation of performance business and success was varied. The interviews with women entrepreneurs in Malang produce some interpretation of success.

\subsection{Continually Develop as a Means of Success for Women Entrepreneurs}

Exploring the meaning of success for women entrepreneurs was defined by the informants based on their experience, which was their intentional expression in managing their businesses to reach success. In human social relations, it is never free from the motives of human actions. In their intersubjective consciousness, humans exchange motives through the process of imagining themselves in the position of others and looking at things through other people's perspectives. This motive is divided into two types, namely, 'because of' motives and 'in order to' motives.

The first motive refers to the experience of humans when they look back on their activities and tend to be pastoriented. The second motive is a goal that is described as intentions, plans, hopes and interests desired by the actor and future-oriented. When we know the typology of motives, we will understand why someone does or does not take action. Then, each of these motives leads to the implications for the establishment of social categories, which leads to a specific identity. These identities are a typification in the construction of social reality based on the behavioral habits of entrepreneurs. In the interpretation of success, women entrepreneur in Malang revealed that they never categorize 
the success when managing their business, as said by participants as follows:

"I never say success other than continue to grow. If we can grow continually, the people would see our success. We only set the target, and other people judge the success of our business. And success is when we can reach the target."

The entrepreneur is an agent who buys means of production at specific prices to combine them. Raymond and Russel defined entrepreneurship by emphasizing the aspect of business freedom, which is stated as follows: An entrepreneur is an independent, growth-oriented owner-operator. Many people with various educational backgrounds want to become successful entrepreneurs. However, developing a small or micro business into a medium and large business requires not only an educational background, but also a mature strategy so the venture can grow and follow what expectation is.

Entrepreneurial success is traditionally associated with business performance, which is mostly determined by the growth and survival of the company (Fairlie \& Robb, 2009). But business growth is a deliberate choice that depends on various factors such as environmental conditions and type of business. For women, in particular, the socialization process can play a crucial role to determine the decision of their growth of the business (Morris, Miyasaki, Watters, \& Coombes, 2006).

One of the criteria that identify the company success is sustainability to survive (Agarwal, Echambadi, Franco, \& Sarkar, 2004; Bollingtoft, Ulhoi, Madsen, \& Neergaard, 2003; Kropp \& Zolin, 2005). The results of this study defined the criteria for success in words to develop continually as an effort to be able to continue the business for an unlimited period (Kuratko, Ireland, \&Hornsby, 2001). To have favorable long-term business prospects, a business must have excellent solvency so it will have sufficient financing to maintain its competitive advantage (Littunen \& Tohmo, 2003; Mitra, 2002). Based on the description above, a research proposition can be made as follows: the meaning of success for women entrepreneurs is continually developing the running of a business.

\subsection{Useful to Others}

The respondent explained exploration of the meaning of success for women entrepreneurs based on experience, which is an expression of awareness in carrying out their respective businesses so that they get success and find answers that are intersubjective. Intersubjectivity is a common understanding or experience between subjects (informants). A person's perception is considered objective if several subjects have the same view of the observed object, then there is an intersubjective relationship to determine the objectivity (Luc, 2020). The others interview with respondents stated that they interpret success when they are useful to others as they said:

"I thought that I am a success if many people need me. I still keep learning, and I thought that I could not do something so that I learn and I do. So, the term of success for me is when I can help people."

while another respondent said:

"Success for me is when I can share with others. So, when I do my business, no matter how much profit I got, as long as I can make others happy, I am success doing my business. Entrepreneurial success for me does not depend on the profit, but relation".

Based on the explanation of the two respondents above, it was found that there was an inter subjectivity of answers to the meaning of success for women entrepreneurs. Interaction is existing among others. Human beings are naturally created as individual beings and social beings. Every person, making social adjustments, is different in many ways from the another. The human association is one form of communication events in society. Many things can be shared, such as information, ideas and attitudes. Likewise, with the opinion of Meril and Lowenstein (1971) that in the human association, there is always a mind adjustment process and the creation of symbols that will contain a shared understanding. Communication is the process of transferring information from and for one person or group of people by using certain symbols that will provide individual influences.

Satpayeva, Kireyeva, Kenzhegulova and Yermekbayeva (2020) defines social adjustments as harmonious journeys or relationships with the social environment to learn the behavior patterns needed to change existing habits that are suitable with values and needs of a society in order to be accepted. Luc (2020) provides a concept of social adjustment as the capability of someone for self-adjustment to others in general and groups, in particular. Furthermore, Luc (2020) also said that the term of self-adjustment also refers to how much someone is useful in society. Modern society, which is complicated as a product of technological progress, mechanisms, industrialization, and urbanization, will raise many problems that have a negative impact. These social problems happen because of a deviation from the ideal society concept. The concept of a perfect society is influenced by the condition of the community at the time of life. Therefore, social problems can be determined by culture.

Women entrepreneurs can convince themselves to be able to carry on life as an entrepreneur because of their trust and capacity. They are required to develop their creativity in utilizing the available opportunities in entrepreneurial life. 
By building social relationships, an entrepreneur will be able to increase his strength as well as his ability to communicate with others. In the aspect of other actors, an entrepreneur can also build relationships with business partners in the hope of mutually giving business information that will benefit both parties. Realizing the fact that what can guarantee the survival of business did not come alone, women entrepreneurs developed the relationships with the community. These relations were categorized as social relations that are needed to fulfill all necessity, to get socioeconomic resources and to address the encountered difficulties.

Entrepreneurship is not easy. Not only considering the economic aspects, but a competent entrepreneurs must also realize the importance of the social and environmental issues of the business they are initiating. If it is only concerned with economic benefits alone without having a positive impact on society and the environment, the venture will not survive. Therefore, every entrepreneur needs to apply sustainable principles in every decision they make. By embracing society and community aspects, business activities can create mutual success. However, there are many challenges faced by entrepreneurs in realizing sustainable entrepreneurs. In terms of sustainability, entrepreneurs who are sensitive to social and environment must be able to embrace the three aspects, namely economic, social and environmental, into a business activity. Therefore, the challenge ahead is how a business will not only benefit for owners but also provide economic benefits for the surrounding community. Business activities that synergize and continue to grow will be able to create sustainable entrepreneurship that will ultimately create mutual success.

Orlitzky, Schmidt, and Rynes(2003)suggested that women entrepreneurs would contribute back to society. Satpayeva, Kireyeva, Kenzhegulova and Yermekbayeva (2020) reveal that some entrepreneurial activities related to social and environmental welfare including providing funds for charity, community activities, and environmentally-friendly activities. Recent discussions about social entrepreneurship specifically relate to social and environmental activities as criteria for success. The success was not only referring to the development of a product, that looks good or tastes good, but personal attitude and how to serve the others are also important in entrepreneurship (Lee \& Kim, 2019). Based on the description above, a research proposition can be made as follows: the meaning of the success of women entrepreneurs is when they are useful and share with others.

\subsection{The Ability to Fulfill Their Needs}

Wealth acquisition, recognition, and growth have been considered as normative criteria for the success of entrepreneurs in recent decades (Littunen, 2000; Wang, Watkins, Harris, \& Spicer, 2004). Some studies emphasize the success criteria related to aspects of success in management and finance to maximize profits and growth. However, personal understanding values as the primary key to the success of a venture owner is equally important, because it relates to the prosperity and financial success of the venture owner.

In interpreting success, based on in-depth interviews with research subjects, it was revealed that the meaning of success is when they can meet their needs, as follows:

"Success, in my opinion, is when I was able to meet my needs, such as want to have my own home, now I am still staying in the house of my parent-in-law". I am thankful that my business is growing, I already have a halal certification code from MUI Malang, which there as not many in chips business that already has the code. It's hard and complicated how to register ... but, yeah, I want to, with this venture will result in profits that can later fulfill my desires ..."

Interviews with the women entrepreneurs showed that they interpret success when they can meet their needs. This interpretation was included in the criteria of individual satisfaction or intrinsic appreciation (Kuratko, Ireland, \& Hornsby 2001; Newby, Watson, \& Woodliff, 2003). Besides financial returns as the goals of entrepreneurs, they also strive to meet personal goals. The personal satisfaction of entrepreneurs can be considered an essential performance of the venture (Cooper \& Artz, 1995). Several studies have identified that personal achievement was the prime reason why they establish the venture (Bennett \& Dann, 2000; Paige $\&$ Littrell, 2002). This is consistent with the results of our indepth interviews of SMEs owners who say their 'success' is when their venture increases their overall satisfaction to be able to meet all their needs. Based on the description above, a research proposition can be made as follows: the meaning of the success of women entrepreneurs is the ability to meet their needs.

\section{Conclusions}

Although there is much research on both measurement and identification of achievement indicators for entrepreneur success, what criteria used to measure the success of women entrepreneurs has been poorly examined. Some past studies have only included very few requirements for success. Finally, this study found some meaning of success from the perspective of women entrepreneurs. The first meaning is to define success by continuing to grow in doing business in the future. Second, success is when they can be useful to others. Furthermore, besides social performance as a goal to be achieved by entrepreneurs, the ability to meet their needs was the primary motivation why they establish 
the venture. This criterion can be categorized the same with the primary motive of women entrepreneurs such as personal satisfaction/intrinsic appreciation, staff-customer relations, family-related goals, and time flexibility. This study has several limitations. First, our sample size is too small. Related to this, our sample consists of entrepreneurs from Malang who are willing to be interviewed and have an average age above 40 years. Hopefully, further research will be able to generalize our findings to a broader sample in various industries outside the city of Malang. As our research shows, the criteria and meaning of success may be different for a larger sample of entrepreneurs.

\section{References}

Agarwal, R., Echambadi, R., Franco, A. M., \& Sarkar, M. B. (2004). Knowledge transfer through inheritance: spin-out generation, development, and survival. Academy of Management Journal, 47, 501-522. doi: 10.2307/20159599

Alam, S. S., Jani, M. F. M., \& Omar, N. A. (2011). An empirical study of success factors of women entrepreneurs in Southern Region in Malaysia. International Journal of Economics and Finance, 3(2), 166-175. doi: 10.5539/ijef.v3n2p166

Al-Tmeemy, S., Abdul-Rahman, H., \& Harun, Z. (2010). Future criteria for success of building projects in Malaysia. International Journal of Project Management, 29(3), 337-348. https://doi.org/10.1016/j.ijproman.2010.03.003

Arena, M., Azzone, G., \& Bengo, I. (2015). Performance measurement for social enterprises. International Journal of Voluntary and Nonprofit Organizations, 26(2), 649-672. https:// doi.org/10.1007/s11266-013-9436-8

Baum, J. R., \& Locke, E. A. (2004). The relationship of entrepreneurial traits, skill and motivation to subsequent venture growth. Journal of Applied Psychology, 89, 587-598. 10.1037/0021-9010.89.4.587

Bennett, R. \& Dann, S. (2000). The changing experience of Australian female entrepreneurs. Gender, Work and Organization, 7, 75-83. https://doi.org/10.1111/1468-0432.00095

Bollingtoft, A., Ulhoi, J. P., Madsen, H., \& Neergaard, H. (2003). The effect of financial factors on the performance of new venture companies in High Tech and Knowledge- Intensive Industries: An empirical Study in Denmark. International Journal of Management, 20, 535-547.

Buttner, E. H., \& Moore, D. P. (1997). Women's organizational exodus to entrepreneurship: Self-reported motivations and correlates with success. Journal of Small Business Management, 35(1), 34-46.

Conner, K. R., \& Prahalad, C. K. (1996). A Resource-based Theory of the Firm. Organization Science, 7, 477-501.

Cooper, A. C., \& Artz, K. W. (1995). Determinants of satisfaction for entrepreneurs. Journal of Business Venturing, 10, 439-457.

Csikszentmihalyi, M. (2003). Good business: leadership, flow, and the making of meaning. New York, NY: Penguin Group.
Davidsson, P., Delmar, F. \& Wiklund, J. (2007). Entrepreneurship and the growth of firms. Cheltenham, UK: Edward Elgar Publishing Limited.

Dvir, D., Sadeh, A., \& Malach-Pines, A. (2010). The fit between entrepreneurs' personalities and the profile of the ventures they manage and business success: An exploratory study. Journal of High Technology Management Research, 21, 43-51. https://doi. org/10.1016/j.hitech.2010.02.006

Fairlie, R. W., \& Robb, A. M. (2009). Gender differences in business performance: evidence from the Characteristics of Business Owners survey. Small Business Economics, 33(375), 1-9. https://doi.org/10.1007/s11187-009-9207-5

Fisher, R., Maritz, A., \& Lobo, A. (2014). Evaluating entrepreneurs' perception of success: development of a measurement scale. International Journal of Entrepreneurial Behavior \& Research, 20, 478-492. https://doi.org/10.1108/IJEBR-10-2013-0157

Freeman, J., Styles, C. \& Lawley, M. (2012). Does firm location make a difference to the export performance of SMEs?. International Marketing Review, 29(1), 88-113. https://doi. org/10.1108/02651331211201552

Gorgievski, M. J., Bakker, A., \& Schaufeli, W. B. (2010). Work engagement and workaholism: comparing the self-employed and salaried employees. The Journal of Positive Psychology, 5(1), 83-96. https://doi.org/10.1080/17439760903509606

Gupta, N., \& Mirchandani, A. (2018). Investigating entrepreneurial success factors of women-owned SMEs in UAE. Management Decision, 56, 219-32. https://doi.org/10.1108/MD-04-2017-0411

Hall, D. T., \& Chandler, D.E. (2005). Psychological success: When the career is a calling. Journal of Organizational Behavior, 26, 155-176. https://doi.org/10.1002/job.301

Hitt, M. A., Ireland, R. D., Camp, S. M., \& Sexton, D. L. (2001). Strategic entrepreneurship: Entrepreneurial strategies for wealth creation. Strategic Management Journal, 22, 479-91. https://doi.org/10.1002/smj.196

Kropp, F., \& Zolin, R. (2005). Technological entrepreneurship and small business innovation research programs. Academy of Marketing Science Review, 2005, 1-14. http://hdl.handle. net/10945/38775

Kuratko, D. F., Ireland, R. D., \& Hornsby, J. S. (2001). Improving firm performance through entrepreneurial actions: Acordia's corporate entrepreneurship strategy. Academy of Management Executive, 15(4), 60-71.

Lai, K. P., Nathan, R. J., Tan, K. S., \& Chan, B. B. (2010). Effect of innovation to the success of female entrepreneurs. Journal of Innovation Management in Small and Medium Enterprises, 2010(2010), Article ID 369877, 1-14. DOI: 10.5171/2010.369877

Lee, W. S., \& Kim, B. Y. (2020). The Effects of career orientations on entrepreneurial satisfaction and business sustainability. Journal of Asian Finance, Economics and Business, 6(4), 235-248. https://doi.org/10.13106/jafeb.2019.vol6.no4.235

Littunen, H. (2000). Entrepreneurship and the characteristics of the entrepreneurial personality. International Journal of 
Entrepreneurial Behaviour \& Research, 6, 295-309. https://doi. org/10.1108/13552550010362741

Littunen, H., \& Tohmo, T. (2003). The high growth firm in new metal-based manufacturing and business Services in Finland. Small Business Economics, 21(2), 187-200. https://doi. org/10.1023/A:1025014427294

Luc, P. T. (2020). Outcome expectations and social entrepreneurial intention: integration of planned behavior and social cognitive career theory. Journal of Asian Finance, Economics and Business, 7(6), 399-407. https://doi.org/10.13106/jafeb.2020. vol7.no6.399

Lumpkin, G. T., Moss, T. W., Gras, D. M., Kato, S., \& Amezcua, A. S. (2013). Entrepreneurial processes in social contexts: how are they different, if at all? Small Business Economics, 40(3), 761-783. https://doi.org/10.1007/s11187-011-9399-3

Masuo, D., Fong, G., Yanagida, J., \& Cabal, C. (2001). Factors associated with business and family success: a comparison of single manager and dual manager family business households. Journal of Family and Economic Issues, 22(1), 55-73. https:// doi.org/10.1023/A:1009492604067

Meril, J. C., \& Lowenstein, R. L. (1971). Media, Messages and Men: New Perspectives in Communication. New York, NY: McKay.

Mitra, R. (2002). The growth pattern of women-run enterprises: An empirical study in India. Journal of Developmental Entrepreneurship, 7(2), 217-237. https://doi. org/10.1177/2277977913480654

Morris, M. H., Miyasaki, N. N., Watters, C. E., \& Coombes, S. M. (2006). The dilemma of growth: Understanding venture SIZE Choices of women entrepreneurs. Journal of Small Business Management, 44(2), 221-244. https://doi.org/10.1111/j.1540627X.2006.00165.X

Moustakas, C. (1994). Phenomenological research methods. Thousand Oaks, CA: Sage Publications.

Newby, R., Watson, J., \& Woodliff, D. (2003). Using focus groups in SME research: The case of owner-operator objectives. Journal of Developmental Entrepreneurship, 8(3), 237-246.

Orlitzky, M., Schmidt, F., \& Rynes, S. (2003). Corporate social and financial performance: A meta-analysis. Organization Studies, 24, 403-441. https://doi.org/10.1177/0170840603024003910
Paige, R. C., \& Littrell, M.A. (2002). Craft retailers' criteria for success and associated business strategies. Journal of Small Business Management, 40, 314-331. https://doi. org/10.1111/1540-627X.00060

Reaves, B. (2008). Entrepreneurial Success: A Phenomenological Study of the Characteristics of Successful Female Entrepreneurs. Doctor of Business Administration Dissertation. University of Phoenix, Phoenix, AZ 85040, United States.

Satpayeva, Z. T., Kireyeva,A.A, Kenzhegulova, G., \& Yermekbayeva, D. (2020). Gender equality and women business of framework 5Ms in Kazakhstan: Analysis and basic directions. Journal of Asian Finance, Economics and Business, 7(3), 253-263. https:// doi.org/10.13106/jafeb.2020.vol7.no3.253

Simpson, M., Tuck, N., \& Bellamy, S. (2004). Small business success factors: The role of education and training. Education \& Training, 46(8-9), 481-491.

Storey, D. J. (2011). Optimism and chance: The elephants in the entrepreneurship room. International Small Business Journal: Researching Entrepreneurship, 2011, 1-9. DOI: $10.1177 / 0266242611403871$

Sorokhaibam, R., \& Laishram, N. (2011). Women entrepreneur in manipur, North-East India. Interdisciplinary Journal of Research in Business, 1(5), 46-53.

Tambunan, T. T. H. (2018). The impact of the economic crisis on micro, small, and medium enterprises and their crisis mitigation measures in Southeast Asia with reference to Indonesia. Asia Pacific Policy Study, 6(1), 1-12. https://doi.org/10.1002/ app5.264

Wang, Y., Watkins, D., Harris, N., \& Spicer, K. (2004). The relationship between succession issues and business performance: Evidence from UK family SMEs. International Journal of Entrepreneurial Behaviour \& Research, 10, 59-84. $10.1108 / 13552550410521380$

Yi, H. T., Han, C. N., \& Cha, Y. B. (2018). The Effect of entrepreneurship of SMEs on corporate capabilities, dynamic capability and technical performances in South Korea. Journal of Asian Finance, Economics and Business, 5(4), 135-47. http:// doi.org/10.13106/jafeb.2018.vol5.no4.135 